\title{
Visions for Urban Landscape Sustainability, Past, Present and Future
}

\author{
Dina Salem ${ }^{1}$
}

\begin{abstract}
Sustainable landscape is widely understood as a key contributor to urban sustainability for the fact that all landscapes has a social, economic, cultural and ecological function for the community's wellbeing and quality of life. This paper briefly reviews the concepts of landscape planning and its role in creating urban quality even before sustainability oriented developments; Sustainable development and the changes in its interpretation as well as visions for landscape sustainability are demonstrated, defined and classified. Challenges facing sustainable landscape planning are discussed. Finally, the paper discusses how our future urban open spaces could be sustainable and how does this contribute to urban sustainability pillars.
\end{abstract}

Keywords: Sustainable urban landscape, socio-ecological sustainability, green infrastructure

\section{Sustainable development and the changes in its interpretation}

The origins of landscape sustainability can be traced to sustainable development, Sustainable development is a fluid concept and various definitions have emerged over the past two decades. Despite the on-going debate, a few common principles tend to be emphasized. Sustainable development is intended to encompass environment, economy, and social issues; but is often realized as an environmental issue. The term, sustainable development, u Environment and Development in 1987. Also known as the Brundtland report, Our Common Future included the "classic" definition of sustainable development: "development which meets the needs of the present without compromising the ability of future generations to meet their own needs." (Murphy\& Drexhage, 2012) The report emphasizes the need to balance the three Es of sustainability: the environmental, economic, and equity concerns for current and future generations. This definition has guided the sustainability paradigm for several decades, but scientists and policy experts have emphasized the need for a broader, holistic, and integrated approach that addresses the connections between human wellbeing and the environment (Selman, 2006).

However, a variety of definitions and interpretations offered since then whose perspectives have ranged from deep ecology to better life quality for people (fig.1)(Kidd, 2007). The shift in sustainability interpretation is shown in the definition developed by the URBAN21Conference in Berlin, 2000 which defined sustainable urban development as: "Improving the quality of life in a city, including ecological, cultural, political, institutional, social and economic components without leaving a burden on the future generations (Hall \& Pfeiffer, 2000). The focus lies upon the long-term improvement of 
quality of life and environmental quality, which is based on maintaining or improving the natural capital (Selman, 2006). In spite of these varieties in sustainability interpretations, landscape contributions to urban sustainability are a common or even a key contributor.

\begin{tabular}{|c|c|c|}
\hline $\begin{array}{l}\text { Conservation strategies: } \\
\text { 1980s } \\
\text { Maintaining essential } \\
\text { ecology and biodiversity }\end{array}$ & $\begin{array}{l}\text { The common } \\
\text { inheritance: } 1999 \mathrm{~s} \\
\text { Responsibility for } \\
\text { future generations }\end{array}$ & $\begin{array}{l}\text { Quality of life: 2000s } \\
\text { Inter and intra equity } \\
\text { of life quality }\end{array}$ \\
\hline
\end{tabular}

Figure 1. Changing interpretations of sustainable development based on (kidd, 2007)

\section{The contribution of landscape to urban quality}

The importance of landscape planning for urban quality is recognized even before the emergence of sustainability concept, landscape architecture has transformed with the city renewal movement post 1860 into core theories of urban renewal and town planning. As Steenbergen states, the role of the park altered from being an "island of landscape in a sea of houses" to becoming an essential component of the urban structure (Knorr, 2011).

\section{Landscape in planning history}

The reconstruction of Paris between 1852 and 1871 was the first example in European urban history where parks and green spaces became an integrated part of city planning; the structure of urban green spaces was based on a comprehensive according to a hierarchical structure (Knorr, 2011). The history of planning shows many other examples that dealt with green space as a basic component of the urban structure such as Emerald Necklace by Olmsted, his parkway first served as a basis for the Metropolitan Park system, designed by Charles Eliot. The extended system improved undeveloped and polluted land, into a system of interconnected green spaces, the integrity of this system was highlighted by the parkways designed to connect the parks to each other and to the city overall (Shibley\& Schneekloth, 2008).

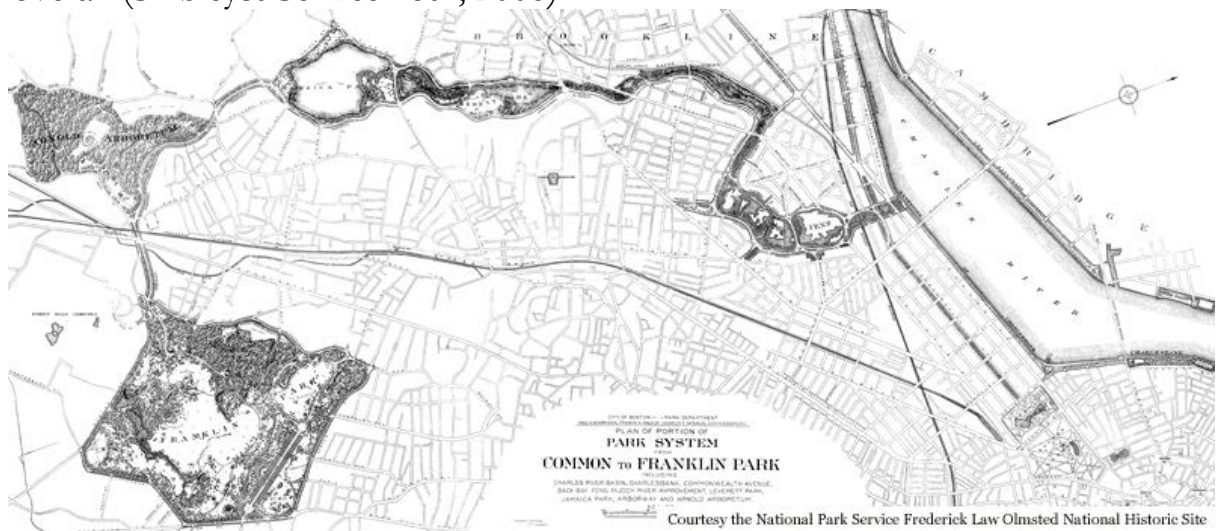

Figure2. Emerald Necklace by Frederick Law Olmsted, Boston, diagram for the Metropolitan Park System 1899 Source: http:// www.olmstedfilm.org

The urban reconstruction Vienna was also an influential example of the second half of 
the 19 th century which drew attention to the relation between parks and green spaces as single entities, and urban structures as a whole. The case of the Ringstraße in Vienna is a well-known example of circular green systems, the ring determined the physical development of the city then a second green ring was proposed by German architects, Joseph Stübben and Otto Wagner. The Gürtelstraße remains an important recreational area for the citizens of Vienna(Knorr, 2011).

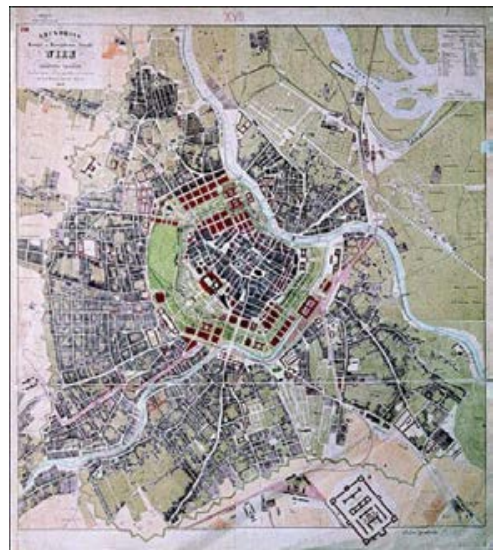

Figure 3. Project of the Ringstrasse, Vienna, Source: www.wien.gv.at

Publications and plans by Joseph Stübben were also influential in relating landscape availability to urban quality. Garden Cities of Ebenezer Howard with its inter-connected urban nodes valued good living conditions, democracy, nature, human rights. In Ville Radieuse by le Corbusier, Parks would exist between the residential units allowing residents with a maximum of natural daylight, a minimum of noise and recreational facilities at their doorsteps.

In spite of the criticism these urban structures had faced they demonstrate how landscape is qualified to organize the city, while positively contributing to the urban experience (Benedict \&McMahon, 2006).

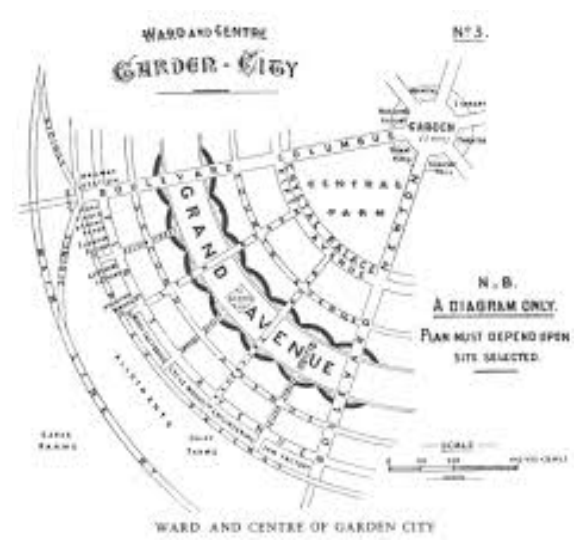

Figure 4. Howard's garden cities

Source: wnw.scodpub.wordpress.com

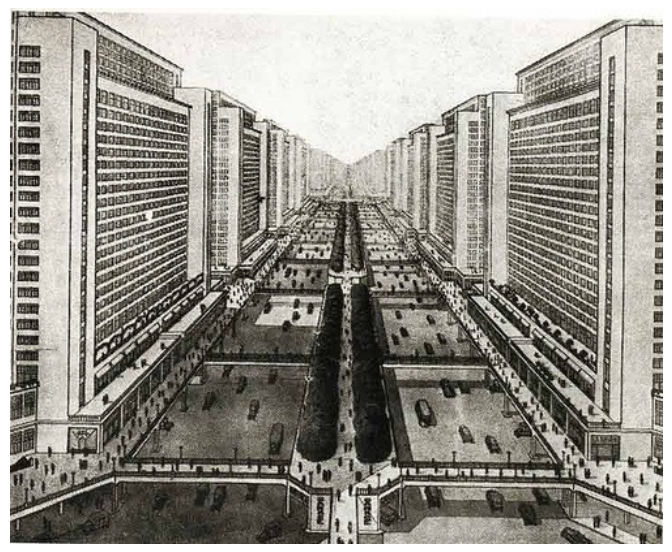

Figure5. Ville Radieuse by le Corbusie Source: wnw.archdaily.com

\section{Landscape for sustainable urban development}

For Lynch, the city is first and foremost a human habitat, and he judged "good city form" by how well it sustains human life (Lynch 1981). Lynch focused on how people perceive the city, proceeding from human perception to understanding the sense of place. He explored the role that natural features play in enhancing the identity, 
legibility, coherence, and immediacy of urban form from the scale of the street to that of the region.

The importance of landscape is also illustrated by Richard Rogers (1998) in his vision of Cities for a Small Planet, a vision in which the quality of the urban landscape is a key contributor to city sustainability. This includes not just the extent and quality of open space provision but the shaping of the city itself. Hall and Ward have also developed a coherent set of principles to guide future development along a more sustainable path. An essential component of Hall and Ward's vision for the sustainable city region was the provision of a high-quality public realm within towns and cities with an accessible and well managed open space network (handley et al, 2007).

On the community development scale, the President's Council on Sustainable Development identified "green infrastructure" -which will be discussed in the following section- as one of five strategic areas that provide a comprehensive approach for sustainable community development (President's Council on Sustainable Development, 1999).

Landscape plays an important role in Randolph Hester's vision for sustainable urbanism, in his book Design for Ecological Democracy he summarizes the principles of sustainable urbanism as: (1) Increase diversity, (2) integrate parts of urban ecosystems that have been segregated, (3) consider the many and diffused indirect interconnections of urban systems, (4) follow the flows and cycles of biological processes,(5) evolve the design from the intrinsic character of the locale, (6) rely on renewable energy and resources, (7) live and design within the natural limits of the bioregion, (8) solve multiple problems with few actions, (9) reveal natural processes through design, (10) use democratic decision-making processes, and (11) co-evolve human development, human habitation, and nature to achieve human fulfillment and the restoration of ecosystems.(Hester, 2006).

Some cities have set measures for sustainable development based on certain indicators according to Local Agenda or national guidelines. Quality of life indicators are usually related to aspects such as "amount of public green spaces per inhabitant", "public parks" and "recreation areas" and important factors to make the city liveable, pleasant and attractive for its citizens.

So, whatever the interpretation of sustainable development is, what should be pursued is human well-being and environmental protection together, not at each other's expense. The society needs a holistic approach to the management of the development process, embracing economic, social, cultural and ecological considerations. Landscape is a framework within which this can be done (Roe, 2007).

\section{Landscape as urbanism:"ecological urbanism," and "landscape urbanism,"}

Charles Waldheim in his book "The landscape urbanism reader" defines landscape urbanism as: "a theory of urbanism arguing that landscape, rather than architecture, is more capable of organizing the city and enhancing the urban experience". Adding that "for many, across a range of disciplines, landscape has become both the lens through which the contemporary city is represented and the medium through which it is constructed."(Waldheim, 2006). Michael Van Valkenburgh stated that landscape 
urbanism is primarily a question of understanding how we go about changing traditional urbanism, while Ecological urbanism is about city-making that focuses on the landscape elements and their continuity_it's partly about nature-making in the city, landscape urbanism attempts to shift paradigms from object-based urban design to city-making, and sees landscape as an organizing force. (Interview with Michael Van Valkenburgh, www.asla.org)

Ecologists have usually taken the urban environment as a degraded version of natural conditions, while urban planners mostly focus on urban nature as trees and parks; considering the urban environment as a participant of natural processes require new aspects in the urban planning and design processes (Gaspar, 2006). For landscape urbanism, landscape acts as a model that includes different forces; natural, cultural, economic, social etc, since it is able to include both spatially and temporally aspects. In short how things work in space and time (Corner 2010, Assargård, 2011). From the previous definitions it is obvious that landscape urbanism considers the human nature relationship a basic process for the city while ecological urbanism can be considered a complementary science for the landscape urbanism theory. Through the history of planning, landscape has been a basic part of the city urban structure; with the emergence of ecological sciences, calls for nature conservation started to be considered. Then throughout the different sustainable development visions from its early beginning in the late 80's and its changing interpretation, landscape is a key contributor and sometimes a model for sustainable urbanism.

\section{Visions for landscape sustainability: From landscape conservation to landscape as infrastructure}

Visions for landscape sustainability depend on how landscape itself is seen. The concept of landscape encompasses more than an area of land with a certain use or function. Antrop considers landscape as a synthetic and integrating concept that refers both to a material-physical reality, originating from a continuous dynamic interaction between natural processes and human activity, and to the immaterial existential values and symbols of which the landscape is the signifier. Alexander von Humboldt sees landscape as a holistic entity perceived by humans and having a distinct character or identity (Antrop, 2005a). Selman suggested that landscape can be thought of as comprising the following elements: natural capital which provides irreplaceable service functions and are, effectively, life-support systems, social capital, which refers to the people living in and using the landscape, economic capital and finally the cultural capital, which is the living legacy of shared histories and human-made artifacts (Selman, 2006). For Selman Landscape is a nexus where these capitals congeal and thus where multiple objectives of sustainable planning can be pursued. These concepts are also included in the definition of the European Landscape convention: "Landscape means an area, as perceived by people, whose character is the result of the action and interaction of natural and/or human factors" (Council of Europe, 2000). Today, the concept of 'landscape' is in a profound transition. Landscape does not refer anymore solely to the traditional rural countryside or the spectacular nature. Multiple visions and values exist for the same landscape. A new holistic synthesis necessitates more elaborated trans-disciplinary 
cooperation (Antrop, 2005).

\section{Nature conservation and environmentalism}

The danger of ecological harm was first alerted by Rachel Carson in her book Silent Spring. In 1969, Ian McHarg, published his book Design with Nature, in which he outlined a theoretical and technical basis for ecologically based planning and design stressing the importance of systematic land-use planning according to the relative ecological value and sensitivity of each part of the landscape: "The distribution of open space must respond to natural process" (McHarg, 1969).The idea was to distribute it in such a way as to minimize disruption of ecological processes. Environmental concerns continued to mount throughout the decade. Beginning in the 1980s, the environmental justice movement presented important challenge to mainstream environmentalism. Since its inception in the 19th century, resource conservation and nature preservation has tended to be a middle and upper class social movement focused on the "wise use" of resources for industrial purposes and on the protection of scenic, recreational spaces in landscapes distant from urban centers (Hellmund \& smith, 2006). That perspective focused upon the preservation of inherent landscape qualities and values both natural resources, such as biodiversity, habitats and water, and cultural heritage in their landscape context.

\section{Landscape ecology}

Conservationists and planners recognized that preserving isolated natural areas is not enough and natural areas need to be connected at the regional and landscape scales to protect biodiversity and ecosystem processes (Benedict \& McMahon, 2006). Landscape ecologists and conservation biologists saw landscape sustainability as meeting biodiversity goals; traditionally have focused on the protection of specific sites. Landscape ecology is the emphasis and focus on the spatial patterning of multiple ecosystems in heterogeneous landscapes. Landscape ecology introduced several perspectives and principles that have become fundamental for planners. One such perspective is the spatial dimension of ecological processes. Vertical (topological) relationships are considered together with horizontal (chorological) relationships between the ecosystems (Leitao\&Ahern, 2006). The patch-matrix-corridor model of Forman (1995) offers is of value to Landscape Ecology structural or spatial indicators, the focus of landscape ecology is to analyze the changing spatial structure and mapping function using(Musacchio,2009), that is very useful and essential but does not cover other sustainability dimensions that need to be addressed through urban landscape planning.

\section{Socio-ecological vision and ecosystem services}

Young (2000) proposed the concept of natural capital as a new paradigm for landscape ecology, in particular when applying landscape-ecological principles in sustainable development and landscape management in the countryside. The natural 
capital paradigm suggests that it is not so much the objects themselves that are important, as the natural functions they support or sustain, and ultimately the goods and services they provide for people. According to Potschin and Haines-Young (2006), a sustainable landscape is one which is able to maintain the outputs of ecosystem goods and services that people value or need rather than to developing optimal design solutions (Potschin and Haines-Young, 2006). De Groot (2006) used a similar approach for valuing landscape sustainability translating ecological complexity into a set of limited number of ecosystem functions that generate the goods and services valued by people. Palmer et al. (2004, 2005) recommend that ecologists reconsider how people and nature can coexist in a sustainable world of designed ecosystems (Musacchio, 2009). Opdam \& Termorshuizen (2009) suggested that for landscape ecology to achieve a central position in sustainable landscape development, it has to extend its pattern-process approach by incorporating perceptions of value in its scientific scope (Figure 6). This would allow landscape ecological knowledge to connect the physical structure and functioning of the landscape with the values demanded by its users (Opdam \& Termorshuizen, 2009).

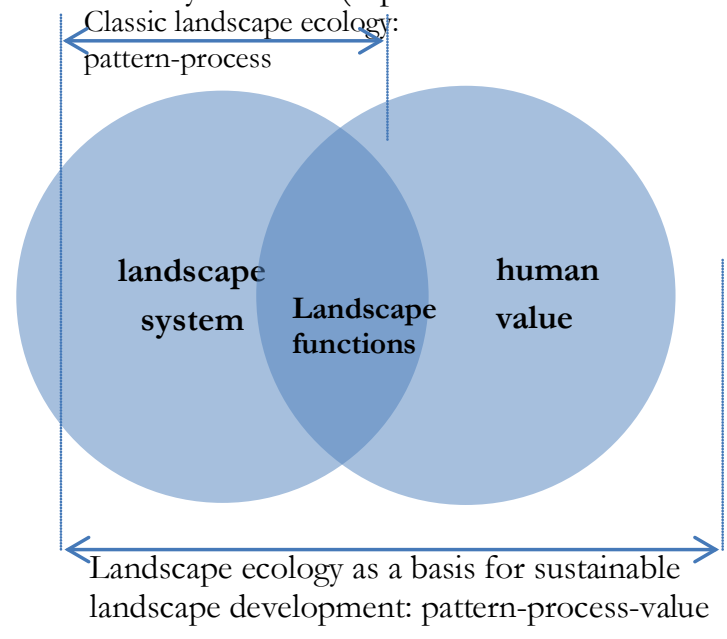

Figure 6. Landscape ecology as a basis for sustainable landscape by extending it to include buman value (Opdam \& Termorshuizen, 2009)

This vision suggests the "services concepts", such as ecosystem services, landscape services can emphasize the connection between physical systems (ecosystems or landscapes) and human values that are essential for the existence and convenience of humanity (Millennium Ecosystem Assessment, 2005).landscape sustainability here is seen as adapting landscapes to provide better services for people. Blaschke (2006) criticized this vision stating that if sustainability at the landscape scale is mainly viewed in terms of maintaining the output of goods and services, then probably many different landscape configurations can be regarded as sustainable adding that "if we only focus on outcomes in terms of benefits how, are we to help people with the issue of where to place things?" (Blaschke, 2006). This extension in the ecological approach is useful in bridging some gaps in landscape planning between ecology and society, but their integration with cultural and aesthetical attributes of landscape sustainability is still unsolved. 


\section{Trans-disciplinary vision}

Tress and Tress (2001) proposed a "transdisciplinary landscape concept" that encompasses five dimensions shown in (Figure 7). The landscape represents a basic spatial unit of society-nature interactions and ought to be the primary "place" of study in sustainability science. It provides a multidimensional meeting ground for ecologists, geographers, social scientists, planners and designers, policy-makers who are all crucial to landscape sustainability research. The landscape is large enough to incorporate key environmental, economic, and social processes and small enough to allow for in-depth and mechanistic studies that produce locally actionable solutions to sustainability problems (Wu, 2012). Some called this vision holistic landscape ecology because landscapes contain distinctive pattern-process relationships that are not only ecological but also cultural, aesthetic, historical, economic, and so on (Musacchio, 2009). Ian Thompson conceived sustainable design as incorporating "ecology, community, and delight," with the last of the three terms referring to the beauty of the landscape and the prospect of creating art with the environment (Thompson, 2000). Based on these visions Musacchio argued that aesthetics or beauty, experience and ethics are the fourth, fifth, and sixth "Es" of the landscape sustainability. She defined Landscape sustainability as desired targets and plausible outcomes in the design, planning, management, and conservation of designed landscapes that meet the goals of those six "Es"( Musacchio,2009). These concepts are also addressed in Selman's argument about sustainable development, he argues that it can be at the intersection of environment, economy, and society, although these terms are now often expanded into phrases reflecting ecosystem services and limits, fair and durable prosperity, and health and social justice. Many authors also draw attention to a fourth dimension of "political sustainability," referring to governance mechanisms that continuously deliver sustainable development through the use of responsible science and economics. In the case of landscape, it is also uniquely important to consider what might be described as "aesthetic sustainability" (Selman, 2008).

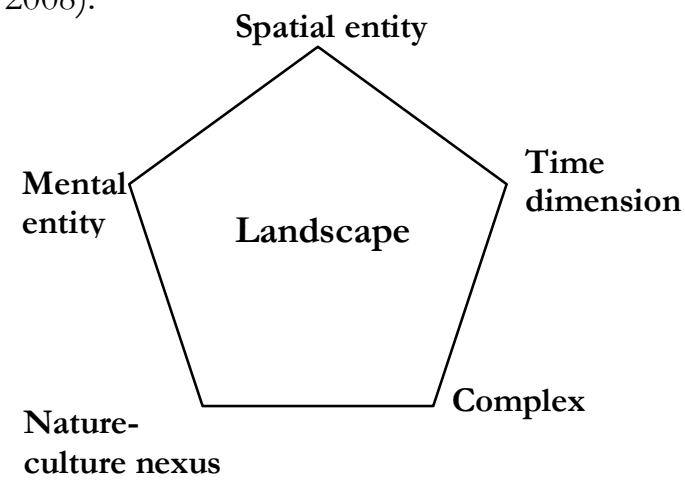

Figure 7. A transdisciplinary concept of landscape based on discussion in Tress and Tress (2001) (Wu, 2012) 


\section{Resilience}

Another vision for the sustainability of any complex adaptive system, including landscapes, is resilience. Holling (1973) defined resilience as: "the ability of a system to absorb change and disturbance without changing its basic structure and function or shifting into a qualitatively different state". More recent work has further developed Holling's (1973) definition by including "the system's abilities to self-organize and adapt to changes, as well as expanding the concept to socioeconomic systems" (Walker and Salt 2006). From a resilience perspective, landscape sustainability is not about maintaining the landscape at a steady state by reducing the variability in landscape dynamics or optimizing its performance, but rather focusing on the landscape's adaptive capabilities to cope with uncertainties. Landscape resilience term is used to refer to the resilience of an entire landscape, viewed as a spatially located complex adaptive system that includes both social and ecological components and their interactions (Cumming, 2011). Carpenter et al. (2001) described social-ecological resilience using three crucial characteristics: The amount of disturbance a system can absorb and still remain within the same state, the degree to which the system is capable of self-organization and the ability to build and increase the capacity for learning and adaptation. The other two central themes to a resilience approach is how social-ecological systems change over time and the cross-scale effects which disregarding it is one of the most common reasons for failures in natural resource management systems (Pisano, 2012).This theory views a landscape as one able to achieve a state of relative stability through self-regulating feedback (Selman, 2008).Therefore resilience theory deals with landscape as an integrated self-organizing multi-scalar system that is able to absorb and adapt to the socioecological changes over the time.

\section{Livability and quality of life}

There is now a considerable focus upon concepts of 'livability' in relation to all areas of sustainability thinking, and particularly in relation to landscape. What makes an environment livable? How can this be translated into landscape enhancement, and what is livability anyway (Roe, 2007). Generally indicators of quality of life for the citizens are always related to urban open spaces, which are equally accessible to the public- citizens and as it can enhance visual experience, social and physical health. The American Society of Landscape Architects believes that communities are more livable when they respect ecological and cultural systems, promote economic development, strive for social equity, and provide places for positive social interaction. As they plan for growth and change, all communities should endeavor to be more sustainable and resource-efficient and to provide more options for housing, employment, and recreation (ASLA, 2001). Livability is useful as a holistic approach to sustainability issues, but it is like sustainability can have many different and relative interpretations and with respect to landscape it has to be translated into spatial attributes, so both needs solid indicators and defined targets based on measurable criteria, otherwise livable landscapes are not necessarily sustainable. 


\section{Landscape integrity: Multi-functionality, greenways and green infrastructure}

'Multi-functionality' has become a focus for many landscapes where it is clear that more integrated thinking is needed, as well as a greater understanding concerning the relationships between the driving forces for change and the effects that such forces have upon the landscape (Roe, 2007).The concept of multifunctional landscapes emerged recently during the international conference on multifunctional landscapes held in Roskilde, Denmark, 2000 and resulted in a whole series of publications (Brandt and Vejre 2004a; Fry 2001; Mander and Antrop 2003; Naveh 2001. Recently, researchers have been advocating a multifunctional landscape concept, which includes both the aesthetic aspect and the services it provides to humans (Potschin and Young, 2006). In the same context, Hellmund \& smith suggested that greenways, if implemented carefully, can help conserve some landscape connections and functions. They proposed a broader concept which is believed to hold promise for sustainability, a concept they call landscape integrity. Landscape integrity is to consider the overall quality or health of the landscape, including ecological and social functions. It includes the health of plants and animals, and other qualities embodied in the term ecological integrity, as well as social functions related to economic, recreational, and aesthetic resources, improving the quality of social and civic interaction, and ensuring equitable access to public spaces and the benefits, both economic and intangible, they offer (Hellmund \& smith, 2006).This has led to a more coherent approach to green space planning, especially the recognition of the importance of 'multi-functional green networks' - the so-called 'green infrastructure' which represents the convergence of two significant precedents: (1) the linking of parks and open spaces for the benefit of people, and (2) the linking of natural areas to benefit biodiversity and counter habitat fragmentation (Handley, 2007). "Green infrastructure" is also believed to extend the aesthetic and recreational value of parks and parkways to a crucial role in health, safety and welfare (Benedict \& MacMahon, 2006; Ahern, 2007).

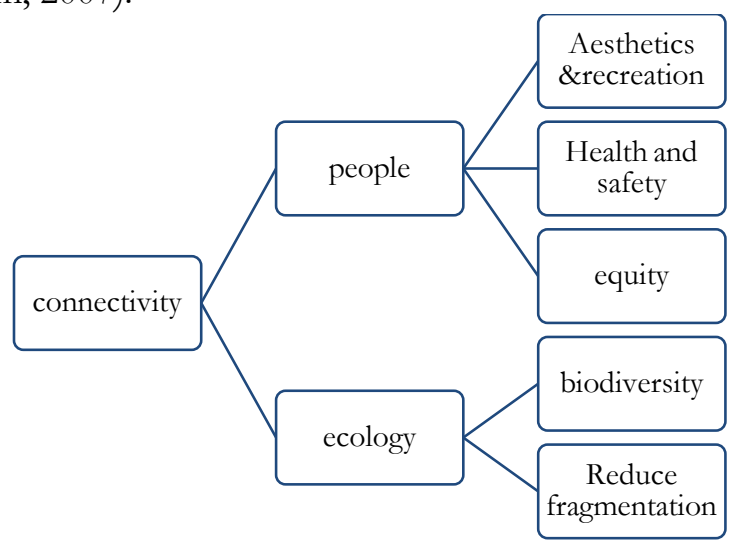

Figure 10. The aim of Green infrastructure: connecting parks and open spaces for people and environment

\section{Landscape sustainability challenges}

History records not only gradual changes in the landscape, but many sudden and 
complete transformations caused by unpredicted natural disturbance and human action (Antrop, 2005). The result is a variety of changes can vary from habitat loss and fragmentation to poverty, income distribution, overpopulation, or market pressures and overconsumption (Linehan\&gross, 1998), that continuous change make us deal with Uncertainties specially when it comes to Assessing and monitoring sustainability and the possibilities for making meaningful quantitative measures that Bell \& Morse called it measuring the immeasurable (Bell \& Morse, 2008).

The variety of sustainability interpretations means multiple perspectives and multiple modes of thinking are needed to solve sustainable transition problems which may be subjective to an extent. Landscape problems are place based and involve multiple scales which make the choice of scale to study sustainability and the correlation among the different scales another challenge to implement and manage sustainable landscape planning.

Another challenge is bridging the gap between research and practice, how does science shape scientific discovery into useful knowledge for application (Musacchio, 2008)?

Finally, the biggest challenge of all is landscape sustainability in dense metropolitan areas and addressing equitable access and sufficient provision deprived communities.

\section{Landscape sustainability towards a future vision}

Selman differentiated between past, present and future nature as follows: Past nature, which is the historical ecology of the landscape, reflecting a balance between natural vegetation cover and geomorphology, and representing a relatively 'low energy' style of landscape management, Present nature, which is the current pattern of greater and lesser 'valued' land covers, of varying degrees of sustainability and future nature, which is the consciously or unintentionally deflected future pattern of land covers and their multi-functionality(Selman, 2006).

He argues that strict preservation approaches are only successful in very particular settings and the role of future nature is to open up possibilities of returning to more naturalistic designs (Selman, 2006). He addressed a range of potential benefits from such sustainable 'futurescapes': they may entail creation, reinforcement, and restoration just as much as protection; it also requires the embedding of political and economic mechanisms that possess the continuous potential to reproduce valued places, it may involve recreation and re-wilding to promote a "future nature resulting in landscape systems sufficiently intact to be self-sustaining and adaptable to climate change. Finally, there is a need to "people" landscapes, not only through participatory processes, but more generally through wider re-connection between communities and place, and a deeper professional appreciation of the ways that local landscapes are walked and talked (Selman, 2008).Multi-functionality becomes an important issue for future landscape sustainability as well as the use of concepts such as natural and human capital and landscape services. (Farlane, 2007) addressed four essential characteristics of multifunctional landscapes: connectivity, utility, diversity and aesthetics. Alternative landscapes offers part of the solution for future landscape sustainability specially in over urbanized areas where environmental justice cannot be achieved by large accessible green areas. Restorative landscapes and local approaches to new sustainable livelihoods, 
working landscapes, land rehabilitation and revitalization are other forms of sustainable landscapes future.

Dealing with uncertainties in landscape change requires a resilience approach rather than a predictive one, a proactive rather than a reactive, our futurescapes needs to be safe from hazards, mitigates climate change, well connected for ecology and people, should be able to efficiently deliver ecosystem services, should be aesthetically pleasing, conserved and above all enhance human social and psychological wellbeing.

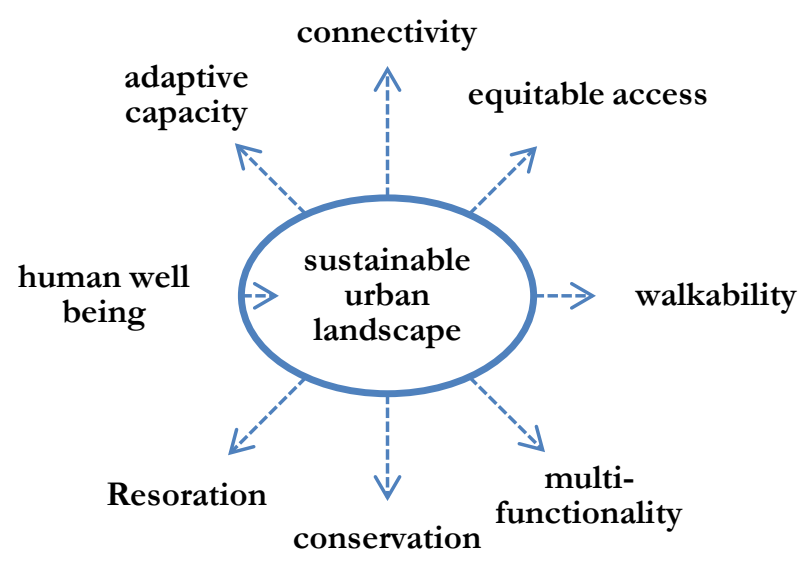

Figure 13. What needs to be addressed in our futurescapes

\section{Conclusion}

The origins of landscape sustainability can be traced to sustainable development, Sustainable development is a fluid concept and various definitions have emerged over the past two decades. Sustainable landscape is widely understood as a key contributor to urban sustainability for the fact that all landscapes has a social, economic, cultural and ecological function for the community's well-being and urban development, that was evident even before the emergence of sustainability concept. The contribution of urban landscape is well illustrated in most of recent visions for sustainable cities and sustainable community besides theories of urbanism argue that landscape is capable of organizing the city and sees landscape as an organizing force and a model for urban structure such as ecological urbanism and landscape urbanism. Visions for landscape sustainability started from nature conservation, then pure ecology focusing on the relation between spatial patterns and ecological processes without considering people as part of the landscape, this was followed by some socio-ecological approaches such as ecosystem services, later on emerged calls for dealing with landscape as a whole system and the most recent visions calls for landscape integrity, multi-functionality and connectivity in the form of greenways and green infrastructure. One of the greatest challenges facing sustainable landscape is landscape change that is considered dealing with uncertainties 
that requires a strong vision for what the future landscape should address. Open spaces conservation, connectivity, accessibility and social-ecological resilience, are to be considered rather than relying on specific predict-and-control measures. Landscape architects should create urban landscapes that become an integral and enriching part of daily life, places that are socially rich rather than homogenizing.

\section{References}

Ahern, J. (2007). Green Infrastructure for Cities: The Spatial Dimension. In Novotny, V., \& Brown, P., (Eds.). Cities of the Future: Towards Integrated Sustainable Water and Landscape Management, London: IWA Publishing, 267-283.

Antrop, M. (2005a). From holistic landscape synthesis to transdisciplinary landscape management. In: Tress, B., Fry, G., \& Opdam, P., (eds), From Landscape Research to Landscape Planning: Aspects of integration, Education and Application. Netherland: Springer.

Antrop,M. (2005). Sustainable landscapes: contradiction, fiction or utopia? Landscape and Urban Planning.

Beatley, T. (2010). Biophilic Cities: Integrating Nature into Urban Design and Planning, Washington, D.C.: Island Press.

Benson, J. \& Roe, M. (Eds.), (2007). Landscape and sustainability (2nd edition). London: Routledge.

Blaschke, T. (2006). The role of the spatial dimension within the framework of sustainable landscapes and natural capital. Landscape Urban Plan. 75 (3-4), 198-226.

Brundtland, G. H., et al. \& World Commission on Environment and Development (1987). Our Common Future, New York: Oxford University Press.

Council of Europe (2002). From perception to protection. Council of Europe publishing. Retrieved from: www.coe.int $/ \mathrm{t} / \mathrm{dg} 4 / \ldots /$ heritage/.../publications_en.asp.

Council of Europe (2006).Landscape and sustainable development. Challenges of the European Landscape convention. Council of Europe publishing. Retrieved from: http:/book.coe.int.

Daniel, T.C. (2001). Whither scenic beauty? Visual landscape quality assessment in the 21st century, Landscape Urban Plan, 54 (1-4), 267-281.

Daniel, T.C., 2001. Whither scenic beauty? Visual landscape qualityassessment in the 21 st century. Landscape Urban Plan. 54 (1-4), 267-281.

De Groot, R. (2006). Function analysis and valuation as a tool to assess land use conflicts in planning for sustainable multifunctional landscapes. Landscape Urban Plan, 75 (3-4), 175-186.

Farlane, R. (2007).Multifunctional Landscapes: conceptual and planning issues for the countryside. In: Benson, J. \& Roe, M. (Eds.). Landscape and Sustainability, (second Edition). London: Routledge.

Forman, R. (1995). Land Mosaics: The ecology of landscapes and regions. New York: Cambridge University Press.

Hall, P., \& Pfeiffer, U. (2000). Urban Future 21: A Global Agenda for 21st Century, London: E\&FN Spon.

Handley, J., Gill,S., \& Pauleit,S. (2007). Landscape sustainability and the city. In: Benson, J. \& Roe, M. (Eds.).Landscape and Sustainability, (second Edition). London: Routledge.

Hellmund, P., \& Smith, D. (2006). Designing Greenways: Sustainable Landscapes for Nature and People. London: Island Press.

Hester Jr., R. (2006). Design for Ecological Democracy. Cambridge: MIT press.

Hill, K. (2007).Visions of Sustainability. In: Benson, J. \& Roe, M. (Eds.). Landscape and Sustainability, (second Edition). London: Routledge.

Kidd,S. (2007). Landscape at the regional scale. In: Benson, J. \& Roe, M. (Eds.). Landscape and Sustainability, (second Edition). London: Routledge.

Kienast, F., Ghosh, S. \& Wildi, O. (2007) (eds.). A changing world: Challenges for landscape research. Netherlands: Springer.

Knorr, L., (2011). The Birth of the Theory of Urban Green Systems in Britain and Hungary, Correspondence between Thomas H. Mawson and Béla Rerrich concerning Urban Design Principles. First International Conference "Horticulture and Landscape Architecture in Transylvania". Agriculture and Environment Supplement 41-53 
Leitao,A., Miller, J., Ahern, J.,McGarigal, K.( 2006). Measuring Landscapes: A Planner's Handbook (Kindle Locations 3740-3741): Island Press. Kindle Edition.

Linehan,J., Gross,M. (1998). Back to the future, back to basics: the social ecology of landscapes and the future of landscape planning. Landscape and Urban Planning 42,(2-4), 207-223.

Millennium Ecosystem Assessment (2003).Ecosystems and Human Well-being: A Framework for Assessment. A Report of the Conceptual Framework Working Groupof the Millennium Ecosystem Assessment. Washington: Island Press.

Musacchio, L. (2009).The scientific basis for the design of landscape sustainability: A conceptual framework for translational landscape research and practice of designed landscapes and the six Es of landscape sustainability. Landscape Ecol (2009) 24:993-1013.

Opdam, P., Steingr"over, E., van Rooij, S. (2006), Ecological networks: a spatial concept for multi-actor planning of sustainable landscapes, Landscape Urban Plan, 75 (3-4), 322-332.

Potschin ,M.\&Young,H. (2005). Landscapes and sustainability(editorial).Landscape and Urban planning. 75 (2006) 155-161.

President's Council on Sustainable Development (1999). Towards a sustainable America May 1999Advancing Prosperity, Opportunity, and a Healthy Environment for the 21st Century, retrieved from: http://clinton2.nara.gov/PCSD/Publications.

Roe, M. (2007). Landscape and sustainability: an overview. In: Benson, J. \& Roe, M. (Eds.). Landscape and Sustainability, (second Edition). London: Routledge.

Roe, M. (2007).The social dimensions of sustainability. In: Benson, J. \& Roe, M. (Eds.). Landscape and Sustainability, (second Edition). London: Routledge.

Rogers, R. (1997). Cities for a small Planet. London: Faber \& Faber.

Sahasrabudhe, S.(2011) .Exploring landscape approach towards livable urban environments IFLA APR Congress - Hospitality: The Interaction with Land.

Selman, P. (2006). Planning at the landscape scale.New York: Routledge.

Selman, P. (2008). What do we mean by sustainable landscape?. Sustainability: Science, Practice, \& Policy 4(2):23-28.

Selman, P. (2012). Sustainable Landscape Planning: The Reconnection Agenda. New York: Routledge.

Selman, P., (2007). Landscape sustainability at the national and regional scale. In: Landscape and Sustainability, (second Edition). London: Routledge.

Shibley, R. \& Schneekloth, L. (2008), The Buffalo Olmsted Park System: Plan for the 21st Century, Buffalo Olmsted ParksConservancy.

Shibley, R. \& Schneekloth, L. (2008). The Buffalo Olmsted Park System: Plan for the 21st Century, Buffalo Olmsted ParksConservancy.

Steiner, F. R. (2002), Human Ecology: Following Nature's Lead, Washington D. C.: Island Press.

Termorshuizen .J.\& Opdam ,P.(2009).Landscape services as a bridge between landscape ecology and sustainable development Landscape Ecol (2009) 24:1037-1052.DOI 10.1007/s10980-008-9314-8.

The Sustainable Site Initiative (2007). Standards \& Guidelines. Preliminary Report. http:www.sustainablesites.org

Thompson, I. (2007).The ethics of sustainability. In: Benson, J. \& Roe, M. (Eds.). Landscape and Sustainability, (second Edition). London: Routledge.

Thompson, I. H. (2000). Ecology, Community, and Delight: Sources or Values in Landscape Architecture. London: E \& FN Spon.

Tress,B., Tress,G., \&van der Valk Gary Fry (Eds) (2003).Interdisciplinary and transdisciplinary landscape studies: Potentials and limitations. Delta series 2. Retrieved from: www.tress.cc/delta/series2.

Walker, B. \& Salt, D. (2006). Resilience Thinking Sustaining Ecosystems and People in a Changing World Washington, DC: Island Press

Walker, B., and Salt, D. (2006). Resilience Thinking: Sustaining Ecosystems and People in a Changing World. 174p. Washington, D.C.: Island Press.

Wu, J. (2012).A Landscape Approach for Sustainability Science Weinstein, M., \& Turner, R., (eds.). Sustainability Science: The Emerging Paradigm and the Urban Environment, Media New York: Springer Science \& Business.

Young, H., Watkins, R.H., Wale, C. (2006). Modeling natural capital: the case of landscape restoration on the South Downs, England. Landscape Urban Plan. 